\title{
The Effect of Employee Empowerment and Work Stress on Employee Organizational Commitment Mediated by Job Satisfaction (Case Study of Financial Services Cooperatives in Denpasar)
}

\author{
I Gede Suriadnyana \\ Universitas Warmadewa, Denpasar, Bali - Indonesia \\ balicertif@gmail.com

\begin{tabular}{|l|}
\hline \multicolumn{1}{|c|}{ Published: 30/09/2020 } \\
\hline How to cite (in APA style): \\
Suriadnyana, I Gede. (2020). The Effect of Employee Empowerment and Work Stress on Employee Organizational \\
Commitment Mediated by Job Satisfaction (Case Study of Financial Services Cooperatives in Denpasar). Jurnal \\
Ekonomi dan Bisnis Jagaditha, 7(2), 92-103. doi: https://doi.org/10.22225/jj.7.2.2156.20-31 \\
\hline
\end{tabular}

\begin{abstract}
A cooperative is a business entity owned and operated by an individual for the benefit of members. The business outgrowth is aligned with the small-medium business expansion in the local area, Bali as general. The objectives of this study are to examine the effect of employee empowerment, job stress, organizational commitment, job satisfaction at the Financial Services Cooperative in Denpasar and to examine the role of job satisfaction in mediating the effect of employee empowerment on organizational commitment at the Financial Services Cooperative in Denpasar. The data for this study conducted from representable cooperatives in Denpasar based on the criteria of a minimum asset, and Good cooperate governance score, this researched collected 63 numbers of respondents by random sampling method. This study is implemented qualitative and quantitative research by spreading the questionnaire to the respondence and also interviewed after the respondence filled up the questionnaire, Partial least square (PLS) has been used as hypothesis testing. The results of this study show that (1). Employee empowerment process is effect positively significant to job satisfaction for the cooperatives employment, (2). Work field pressure has a positive effect on job satisfaction, (3). Work field pressure is positive but insignificantly effect to the organizational commitment, (4). Job satisfaction is showing positive insignificant effect toward the organizational commitment, (5). This research found that mediation factor between commitment and employee empowerment is work satisfaction.
\end{abstract}

Keywords: Employee Empowerment; Job Stress; Organizational Commitment and Employee Job Satisfaction

\section{INTRODUCTION}

The most important factor for the organization and business entities to compete is Manpower Schuler \& MacMillan (1984). Huselid (1995) showed that implementation of human resource management policy has an impact on employee turnover, employee productivity and financial performance of company organization or business entity. Cotton \& Tuttle (1986) reveals that perceptions of job security, the level of employee benefits, and job satisfaction affect organizational commitment. Individual work satisfaction is achieved when an organization can meet individual employee expectations based on the Disconfirmation Expectancy Theory, which subsequently affects the intentions of individual employees to leave the organization and obtain employment in another organization that is judged to be able to meet the individual expectations of the employee. Employee turnover resulting in an efficiency of production processes and distribution decreased due to a change of the new employees are still undergoing a period of orientation after being abandoned by the old employees and at the same time, the operational acceptance cannot be improved.

Problems often encountered by organizations on human resources one of which is how to maintain employee commitment to the company. A cooperative is a business entity owned and operated by an individual for the benefit of members. Cooperatives have a very important role for all societies in conducting financial 
transactions. The development of cooperatives is currently supported by the development of small and medium enterprises (SMEs) in Bali and particularly in the rapidly growing city of Denpasar. Along with the increasing economy in Denpasar, the cooperative is expected to become a provider of funds to finance and develop the business of agriculture, trade, industry, and other non-financial sectors.

The criteria used to measure the effectiveness and efficiency of the business is capital, assets, management, efficiency, independence and growth, liquidity. Measurement of management aspects includes organization and qualified human resources obtained from the training, assignment and discipline of work, that cooperatives that have good organizational commitment reflect the predicate healthy cooperative.

Investigating from the problems faced by cooperatives in Denpasar City, thus in this study, the problems are limited to human resource problems, especially the problem of organizational commitment of cooperative employees. The organizational commitment of the employees in the cooperative needs to be managed professionally to realize the balance between the needs of employees with the interests and capabilities of the cooperative. The balance is the key in the empowerment of employee resources to avoid job stress, maximal work dissatisfaction and persists in competition in the era of globalization. Thus it is increasingly realized that in a cooperative organization, HR is the most important element, as expressed by Hardyansyah (2002) that man as a workforce in the organization has an important role in achieving the goals and provide good service for the organization and society.

Low employee commitment can hinder the achievement of company goals. Other problems faced by companies other than absenteeism are also due to lack of employee loyalty and lack of working hours visible during office hours, where there are still many employees whose arrival hours are over 15 minutes late. The researcher wants to know and understand the extent to which aspects of employee empowerment, job stress affect the organization's commitment to mediation and job satisfaction of the Cooperative Financial Services in Denpasar, the location was selected because there is an indication of the lack of commitment of employees to the organization that can be seen from the results of interviews obtained. Based on the background of the problem above, the objectives of this study are to examine the effect of employee empowerment, job stress, organizational commitment, job satisfaction at the Financial Services Cooperative in Denpasar and to examine the role of job satisfaction in mediating the effect of employee empowerment on organizational commitment at the Financial Services Cooperative in Denpasar.

\section{CONCEPT AND HYPOTHESES}

Muhammad \& Abdullah (2016) empowered employees related to the theory of social exchange (social exchange theory) proposed by Blau about the mutual relationship of employees with the organization. Organizations that support employees and recognize the views of employees in decision making, impact on the high commitment of employees to the organization. Conservation of Resources (COR) theory developed by Stevan Hobfoll, a theory that explains a person will seek to obtain and maintain or retain the resources it possesses, resources here include energy (time) (God et al., 2012). Time is an important thing for employees to do in the work, employees who have limited time and demanded to do a lot of work will make employees lose resources and cause negative circumstances, such as experiencing stress. High stress will make the employee's commitment to the organization decline, whereas favourable conditions will lead to resource gains, when employees feel there is a calm and comfortable atmosphere in the workplace because work is not pursued by time, they will feel happy in spending the rest of their career in the organization and will increase its organizational commitment. 


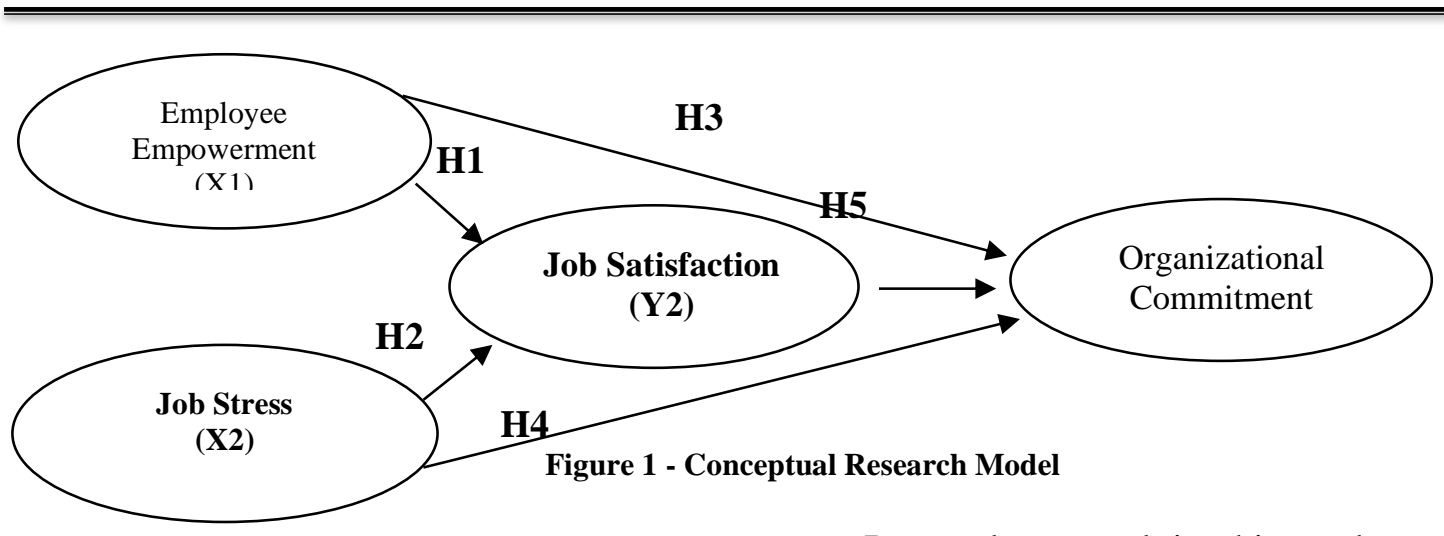

The hypotheses that can be formulated from the concept above are:

H1 : Employee empowerment has a significant positive effect on job satisfaction.

H2 : Job stress has a significant positive effect on job satisfaction.

H3 : Employee empowerment positively affects organizational commitment.

H4 : Job stress has a significant positive effect on organizational commitment

H5 : Influence of positive work satisfaction significantly to the organizational commitment of employees.

H6 : Job satisfaction has a role as a mediator influence the empowerment of employees to organizational commitment.

H7 : Job satisfaction has a role as a mediator of the influence of work stress on organizational commitment

\section{METHODS}

This research is a survey research design to test the correlational correlation of employee empowerment variable, job stress variable and job satisfaction variable to the organizational commitment with data collected from cooperative financial service cooperative organization (KJK) operating in Denpasar area. The population in this research is all employees of Cooperative Financial Services in Denpasar as much as 63 people. The number of respondents in this study is determined by using a simple random sampling method. The data obtained are then analyzed descriptively and inferentially.

\section{RESULT AND DISCUSSION}

Respondents used in this study were mostly female respondents, over 35 years old, educated undergraduate, and with a working period of more than 10 years.

\section{Validity test}

Based on the research data, after validation process, it is found that all statement items on each indicator of employee empowerment, work stress, organizational commitment and job satisfaction are valid because it has correlation coefficient $>0,30$ and t-test is significant at level 0,05 .

\section{Test Reliability}

The results of the research instrument reliability test are shown in Table 5. These results show that the Cronbach Alpha value of each construct is> 0.60 which means that the reliability of all research variables is categorized well and accepted.

\section{Descriptive Analysis}

Descriptive analysis conducted to know the description of each variable seen from the frequency distribution of respondents 'answers to the statement of variables studied for the interpretation of respondents' assessment.

\section{Description of Employee Empowerment Variables}

The average score for the organizational culture variable is 3.91 where the highest average score of the employee empowerment variable is the input I give received in the organization activity planner of 4.37 followed then the indicator I get involved in determining the organizational goals of 4, 06, my indicator can give suggestions for an organizational problem solving of 3.86, the indicator I was involved in when discussing organizational changes of 3.83 , 
my indicator has the freedom to decide how I do a job of 3.78 , the indicator of norms of 3.74 and my indicator is responsible for the work according to my responsibility of 3.60 .

\section{Description of Job Stress Variables}

The average score for the organizational culture variable is 3.85 where the highest average score of work stress variable is that I have to work faster than my ability of 3.98 followed by then my indicator performs the job more than the employee's efforts, in general, doing a job is 3.92 , the indicator I have to do new stuff without work guidance is 3.90 , my indicator must work for longer than the body resistance of 3.81, my indicator does not involve enough time to do all work of 3, 76, and indicators I feel uncomfortable where I work 3.73.

\section{Description of Organizational Commitment Variables}

The average score for the organizational culture variable is 4.10 where the highest average score of the performance variables is work commitment of 4.33 followed then the timeliness indicator is 4.28 , the workload indicator is 4.26 , the craft indicator and the cooperation each of 4.01 , a work quality indicator of 3.73 .

\section{Description of Job Satisfaction Variable}

The average score for the organizational culture variable is 4.10 where the highest average score of the job satisfaction variable is I feel satisfied with my coworkers of 4.25 followed then the indicator of my leadership always gives support in every job implementation of 4,22 , the indicator I am satisfied with the level of responsibility in my work of 3.94, the indicator I am satisfied with the work environment of this organization of 3.83, the indicator I am satisfied with the salary/wages given to me of 3.80 .

\section{Inferential Analysis}

Evaluation of Measurement Model (Outer Model)

\section{A. Convergent Validity}

This evaluation is done through examination of the outer loading coefficient of each indicator to the latent variable. An indicator is said to be valid if the outer loading coefficient is between 0.60 to 0.70 but for theoretical analysis, it is not clear then outer loading 0.50 is recommended Ghozali \& Latan (2012:78) and significant at alpha level 0.05 or t- statistics 1.96. Because there are some indicators that the value of outer loading $<0,50$ (original value of sample (O) is red) and not statistically significant because of the value of T-statistic $<1,96$, then model reconstruction by issuing those indicators. All the outer loading results of the reconstruction results have met the valid requirement that is with the value of index outer loading $>0.50$.

Table 1. Loading Outer Value Estimation Model Results After Reconstruction

\begin{tabular}{|c|c|c|c|c|c|}
\hline $\begin{array}{c}\text { Indikator<- } \\
\text { Konstruk }\end{array}$ & $\begin{array}{c}\text { Original } \\
\text { Sample } \\
(\mathbf{O})\end{array}$ & $\begin{array}{c}\text { Sample } \\
\text { Mean } \\
(\mathbf{M})\end{array}$ & $\begin{array}{c}\text { Standard } \\
\text { Deviation } \\
\text { (STDEV) }\end{array}$ & $\begin{array}{c}\text { Standard } \\
\text { Error } \\
\text { (STERR) }\end{array}$ & $\begin{array}{c}\text { T Statistics } \\
(\mid \mathbf{O S T E R R})\end{array}$ \\
\hline $\begin{array}{c}\text { X1.1 <- } \\
\text { PEMBERDAYAAN } \\
\text { KARYAWAN }\end{array}$ & 0,82 & 0,82 & 0,10 & 0,10 & 8,48 \\
\hline $\begin{array}{c}\text { X1.3 <- } \\
\text { PEMBERDAYAAN } \\
\text { KARYAWAN }\end{array}$ & 0,63 & 0,60 & 0,16 & 0,16 & 3,86 \\
\hline $\begin{array}{c}\text { X2.3 <- STRES } \\
\text { KERJA }\end{array}$ & 0,89 & 0,89 & 0,06 & 0,06 & 15,65 \\
\hline $\begin{array}{c}\text { X2.5 <-STRES } \\
\text { KERJA }\end{array}$ & 0,65 & 0,62 & 0,17 & 0,17 & 3,92 \\
\hline $\begin{array}{c}\text { Y11 <- } \\
\text { KOMITMEN }\end{array}$ & 0,80 & 0,79 & 0,11 & 0,11 & 7,06 \\
\hline $\begin{array}{c}\text { Y12 <- } \\
\text { KOMITMEN }\end{array}$ & 0,75 & 0,74 & 0,12 & 0,12 & 6,33 \\
\hline $\begin{array}{c}\text { Y23 <- KEPUASAN } \\
\text { KERJA }\end{array}$ & 0,78 & 0,77 & 0,08 & 0,08 & 9,34 \\
\hline
\end{tabular}




\begin{tabular}{|c|c|c|c|c|c|}
\hline $\begin{array}{c}\text { Y26 <- KEPUASAN } \\
\text { KERJA }\end{array}$ & 0,86 & 0,86 & 0,05 & 0,05 & 16,28 \\
\hline
\end{tabular}

In Table 1 shows that the entire value of the outer loading results has been qualified valid reconstruction ie with an index value of outer loading $>0.50$ and significant at the 0.05 level $(\mathrm{T}$ statistic values $>1.96)$. The next analysis will use the indicator values in Table 2.

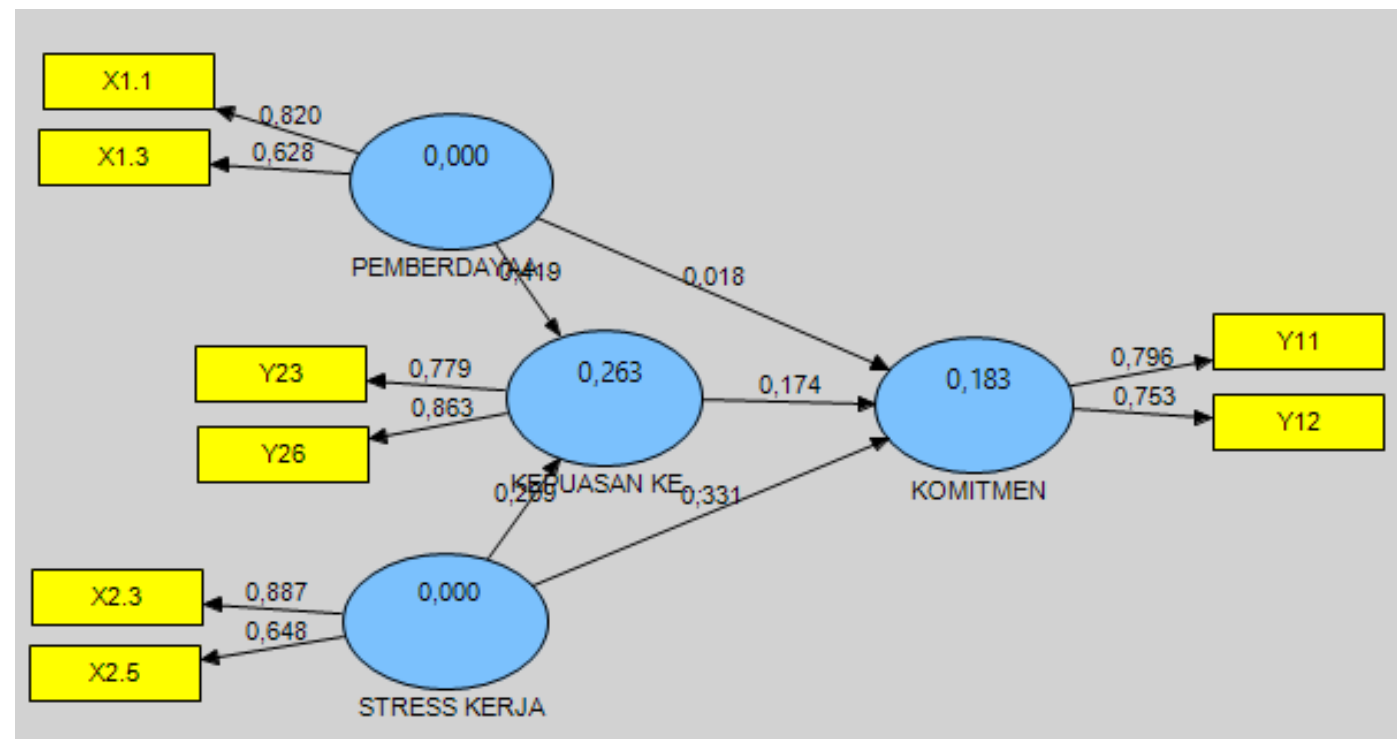

Figure 2. Outer Loading and Path Analysis of Estimated Results After Reconstruction

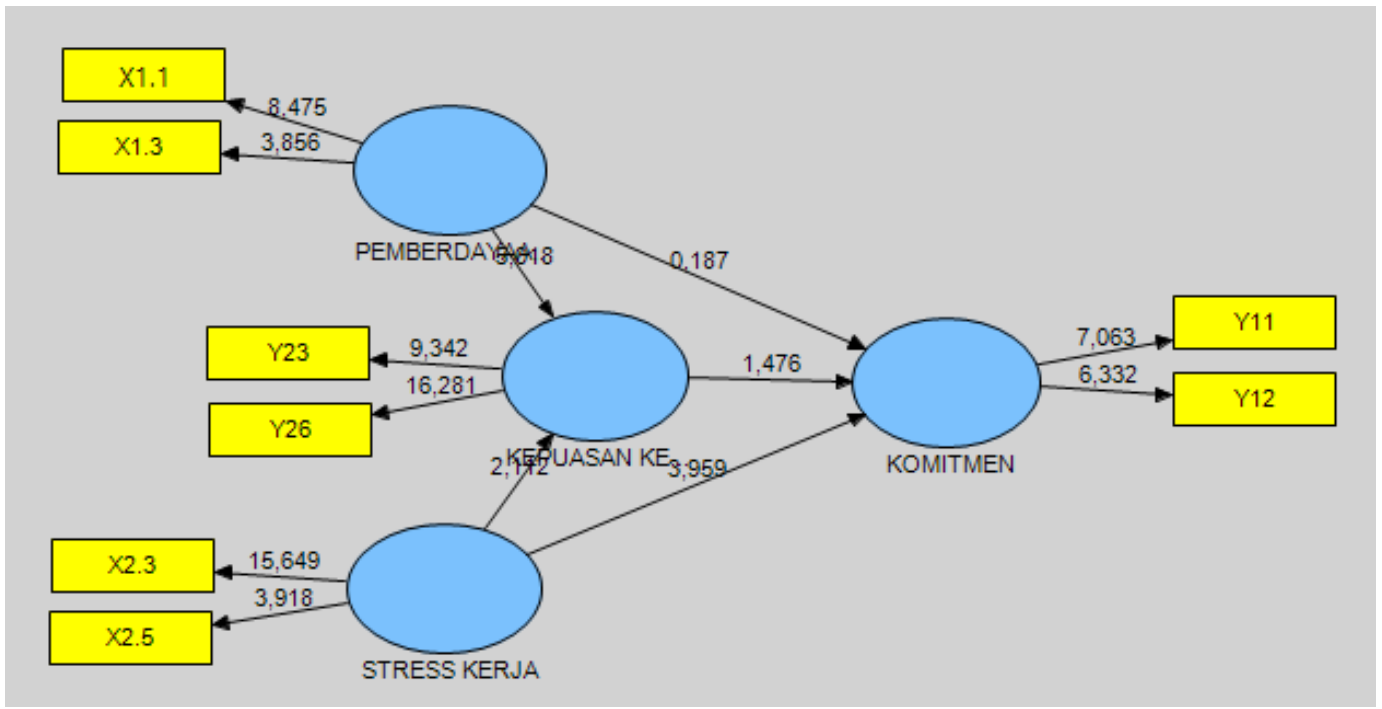

Figure 3. Boothstrapping After Reconstruction (Test Statistics)

\section{B. Discriminant Validity}

Measurement of the validity of the indicators that make up the latent variables can also be done through discriminant validity. Discriminant validity can be done by comparing the AVE Root coefficient ( $\sqrt{A V E}$ or Square root Average Variance Extracted) of each variable with the correlation value between the variables in the model. A variable is said to be valid, if the AVE root ( $\sqrt{A V E}$ or Square root Average Variance Extracted) of each construct is greater than the correlation value between the constructs Ghozali \& Latan (2012:7879), and each AVE value is greater than 0.50 . the value of each construct $\sqrt{ } \mathrm{AVE}$ ranges from 0.73 to 0.82 is greater than the correlation value between constructs of 
magnitude between 0.18 to 0.47 , and the AVE value of each construct> 0.50 (ie ranges between 0.53 to 0.68 , so it is eligible valid based on discriminant validity criteria.

\section{a. Composite Reliability and Cronbach Alpha}

A measurement can be said to be reliable if the composite reliability and Cronbach alpha has a value greater than 0.70. Composite reliability and Cronbach alpha is a measure of reliability between the indicator blocks in the research model. the value of the composite reliability of each construct has shown a value greater than 0.70 except Employee Empowerment is slightly smaller that is 0.69 so that it meets the reliable requirements based on the composite reliability criteria. While the value of Cronbach Alpha shows the value of each construct is lower than 0.70 , so it does not meet the requirements of the Cronbach Alpha index.

\section{Evaluation of Structural Model (Inner Model)}

The structural model evaluation (Inner Model) is a measure to evaluate the level of accuracy of a model in the overall study, formed through several variables along with its indicators.

\section{a. Evaluation of Structural Model Through R-Square (R2)}

The value of job satisfaction $\mathrm{R} 2$ is 0.26 ; based on the criteria of Chin Ghozali \& Latan (2012:85), the model includes the criteria of approaching moderate, the meaning is the variation of employee empowerment and work stress able to explain the variation Job satisfaction of 26 percent, the remaining 74 percent is explained by variations of other variables outside the model analyzed. While the commitment has an R-square value of 0.18 or including a weak model, meaning the variation of empowerment, stress and satisfaction can explain the variation of commitment by 18 percent the remaining 82 percent explained by variations outside the model.

b. Evaluation of Structural Model through Q-Square Predictive Relevance (Q2)

Q-Square Predictive Relevance (Q2) is a measure of how well the observations performed give results to the research model. The Q-Square Predictive Relevance (Q2) value ranges from 0 (zero) to 1 (one). The nearer $\mathrm{Q}$ value of Q-Square Predictive Relevance (Q2), indicates that the research model is getting worse. The value of $\mathrm{Q}$ Square is $=1-(1-\mathrm{R} 12)(1-\mathrm{R} 22))=1-(1-$ $0.13)(1-0.10)=1-0.78=0.22$, based on this result the estimation model is included in the moderate criteria to the quarves, meaning that 22 percent of endogenous constructing variations can be predicted by exogenous construct variations.

\section{c. Evaluation of Structural Model through Goodness of Fit (GoF)}

The goodness of Fit $(\mathrm{GoF})$ is a measure of overall model accuracy (global), as it is considered a single measurement of outer model measurements and inner model measurements. The measurement value based on Goodness of Fit (GoF) has a range of values between 0 (zero) to 1 (one). The value of Goodness of Fit (GoF) is getting closer to 0 (zero), indicating the model the less good, the opposite getting away from 0 (zero) and getting closer 1 (one), then the model the better. The strong criteria for the weakness of the model based on the measurement of Goodness of Fit (GoF) according to Ghozali \& Latan (2012:88), are as follows: 0.36 (GoF large), 0.25 (GoF medium), and 0.10 (GoF small). The calculation by GoF shows a value of $\sqrt{ }$ AR2 $*$ A.Com $=\sqrt{ } 0.22 * 0.60=0.36$ This means that the global model is a good predictive (large).

Table 2. Path Analysis and Testing Statistics

\begin{tabular}{|c|c|c|c|c|c|c|}
\hline Konstruk & $\begin{array}{c}\text { Original } \\
\text { Sample (O) }\end{array}$ & $\begin{array}{c}\text { Sample } \\
\text { Mean (M) }\end{array}$ & $\begin{array}{c}\text { Standard } \\
\text { Deviation } \\
\text { (STDEV) }\end{array}$ & $\begin{array}{c}\text { Standard } \\
\text { Error } \\
\text { (STERR) }\end{array}$ & $\begin{array}{c}\text { T Statistics } \\
(\mid \text { O/STERR|) }\end{array}$ & Keterangan \\
\hline $\begin{array}{c}\text { KEPUASAN KERJA } \\
\text {-> KOMITMEN }\end{array}$ & 0,17 & 0,17 & 0,12 & 0,12 & 1,48 & $\mathrm{not}$ \\
significant
\end{tabular}




\begin{tabular}{|c|c|c|c|c|c|c|}
$\begin{array}{c}\text { PEMBERDAYAAN } \\
\text { KARYAWAN -> } \\
\text { KEPUASAN KERJA }\end{array}$ & 0,42 & 0,43 & 0,08 & 0,08 & 5,02 & significant \\
\hline $\begin{array}{c}\text { PEMBERDAYAAN } \\
\text { KARYAWAN -> } \\
\text { KOMITMEN }\end{array}$ & 0,02 & 0,02 & 0,10 & 0,10 & 0,19 & $\begin{array}{c}\text { not } \\
\text { significant }\end{array}$ \\
\hline $\begin{array}{c}\text { STRES KERJA -> } \\
\text { KEPUASAN KERJA }\end{array}$ & 0,21 & 0,21 & 0,10 & 0,10 & 2,11 & significant \\
\hline $\begin{array}{c}\text { STRES KERJA -> } \\
\text { KOMITMEN }\end{array}$ & 0,33 & 0,36 & 0,08 & 0,08 & 3,96 & significant \\
\hline
\end{tabular}

Table 2 shows that:

1) Job satisfaction has a positive effect of 0.17 on organizational commitment, and the relationship is not significant at the 0.05 level because the value of t-statistic is greater than 1.96 at 1.48 .

2) Employee empowerment has a positive effect on the satisfaction of 0.42 , and the relationship is significant with value $t$ equal to 5,02 bigger than $\mathrm{T}$-table that is equal to 1,96 .

3) Positive employee empowerment of 0.02 to organizational commitment and the relationship is not significant with the value of 0.19 is smaller than the value of t-table is 1.96.

4) Work stress has a positive effect of 0.21 on job satisfaction and the relationship is significant with the value of $t$ arithmetic of 2.11 .1

5) Work stress has a positive effect of 0.33 on organizational commitment and significant with $t$ value of 3.96 .

6) Influence of mediation analyzed includes direct analysis and indirect effect, analysis in this research using the examination method. Method of checking with how to do twice the analysis, that is the analysis by involving the mediation and analysis variable without involving the mediation variable.

The method of examining the mediation variables with the coefficient difference approach is done as follows: (a) examine the direct influence of the Independent Variable on Dependent Variables on the model by involving the mediation variables; (b) check the influence of Independent Variables on Dependent Variables on the model without involving the mediation variables; (c) examining the influence of the Independent Variable on Mediation Variables, and (d) examining the effect of the Mediation variable on the Dependent variable. If (c) and (d) are significant, and (a) are not significant, then customer satisfaction is said to be a complete mediation variable. If (c) and (d) are significant and (a) are also significant, where the coefficient of (a) is smaller (down) than (b) then customer satisfaction is said to be a partial mediation variable. If (c) and (d) are significant and (a) are also significant, where the coefficients of (a) are almost equal to (b) then customer satisfaction is said not as a mediating variable. If either (c) or (d) or both are not significant then it is said not as a mediating variable (Hair \& et al., 2010; Solimun, 2011).

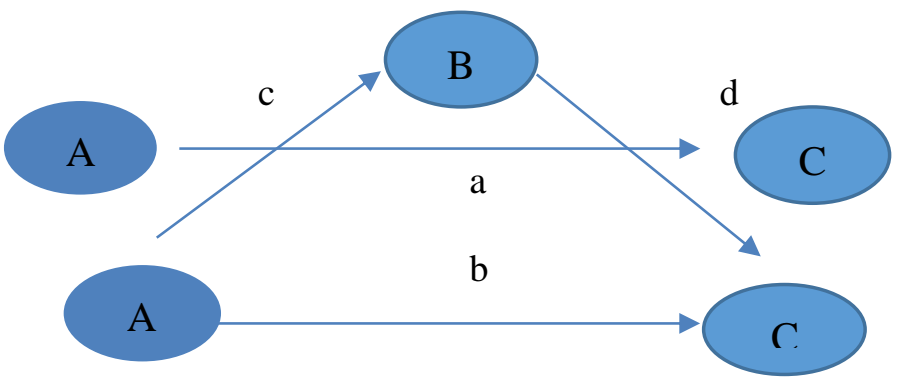

Figure 4. Theoretically the Role of Mediation 
Based on the calculation, then the role of mediation commitment test can be seen in the following Graph 5.

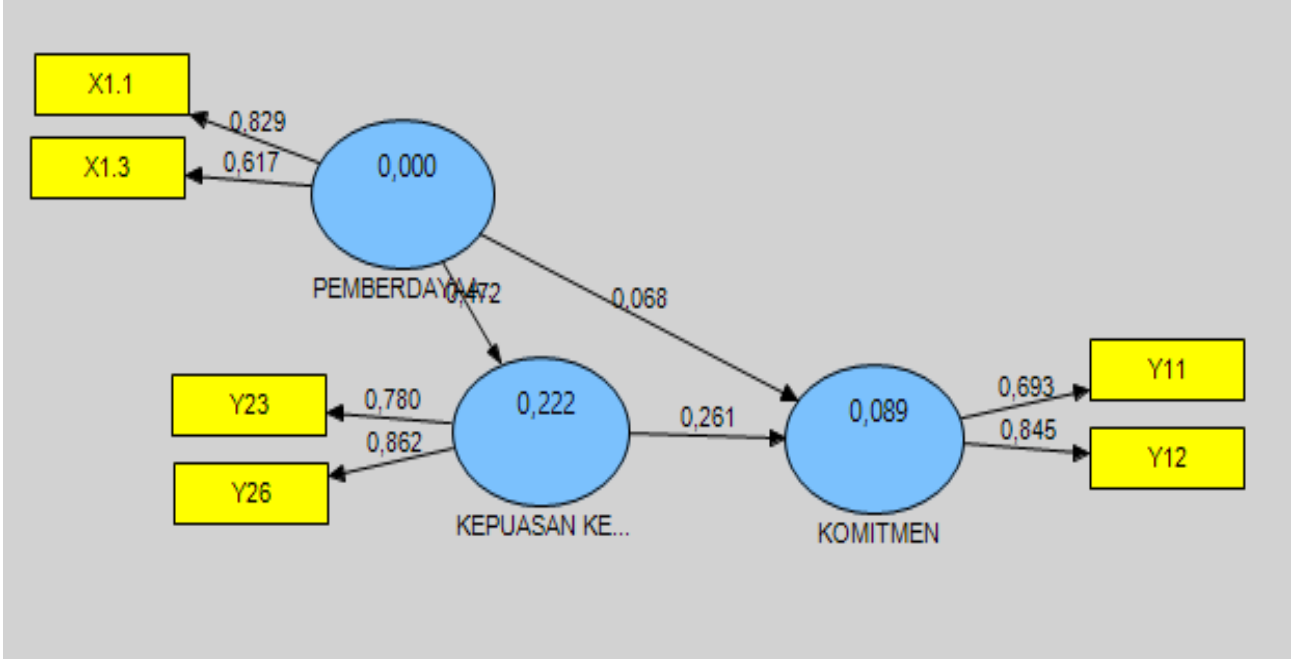

Figure 5. The Role of Satisfaction Mediation on the Empowerment of Commitment

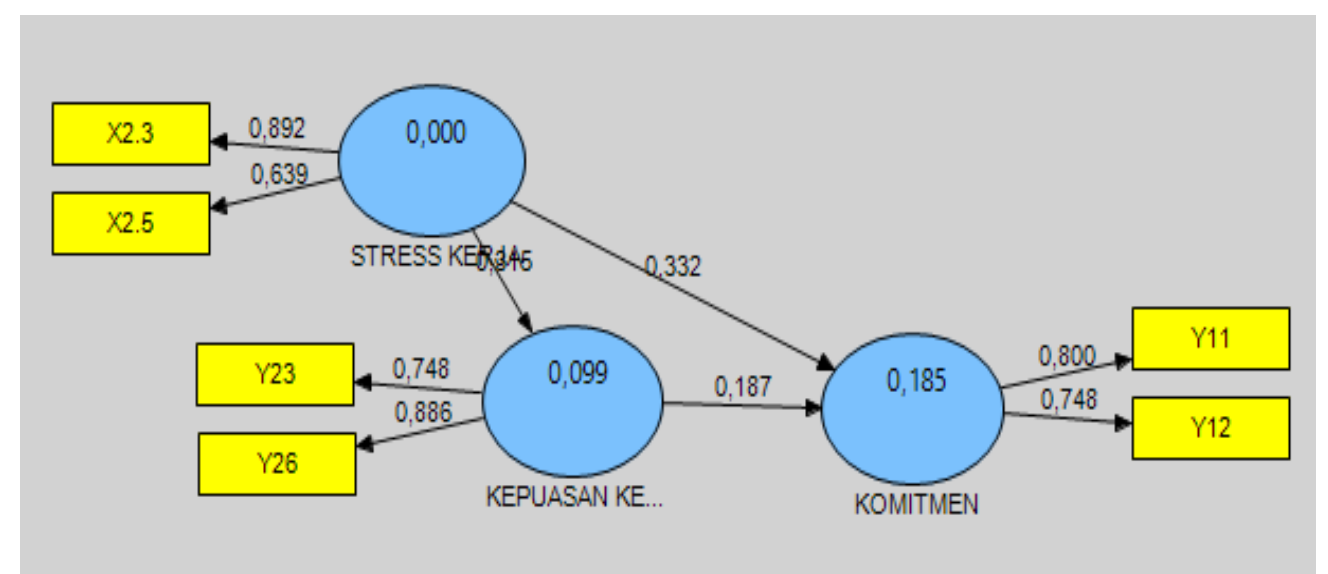

Figure 6. The Role of Mediation of Job Satisfaction on Working Stress on Organizational Commitment

Based on Figure 6, it turns out job satisfaction is not a mediation between work stress on organizational commitment, because the indirect relationship of job stress to job satisfaction is significant while job satisfaction on organizational commitment is not significant. On the other hand, the direct relationship between job stress on organizational commitment is significant.

\section{DISCUSSION}

Influence of Employee Empowerment on Job Satisfaction at Denpasar Financial Services Cooperative

Based on the results of testing on the effect of employee empowerment to job satisfaction, shows that employee empowerment has a positive and significant impact on organizational commitment and the relationship is not significant. Thus the hypothesis in this study which states that employee empowerment positively affects the job satisfaction at the Financial Services Cooperative Denpasar. In terms of employee empowerment indicators, 2 indicators score above average is involved in determining the organizational goals (good) and input that I give received in the planner of organization activities (very good). Thus the hypothesis in this study which states that employee empowerment has a significant positive effect on job satisfaction of employees of Financial Services Cooperative in Denpasar is not proven. 
The results of this analysis in accordance with the statement presented Siagan (2004) which states that the employee is the involvement of employees in the decision-making process. Empowering employees within a company means allowing employees to show their potential and skills. The results of this study are also in line with research Maulana (2015), (Yulianti, 2011), Febriwanti, Zulfadil, \& Samsir (2017), Siallangan (2014), Maulana \& Syah (2016), and (Elnaga \& Imran, 2013) indicating that community empowerment positively affects organizational commitment.

The Influence of Job Stress on Job Satisfaction at Denpasar Financial Services

\section{Cooperative}

Based on the results of testing on the effect of job stress on job satisfaction, showed that job stress positively affects job satisfaction at the Financial Services Cooperative Denpasar. Thus the hypothesis in this study which states that job stress has a significant positive effect on job satisfaction at the Denpasar Financial Services Cooperative. In terms of job stress indicator, 3 indicators score above the average that works faster than the ability (good), carrying out the work exceeds the efforts of employees in general (good) and do new things without the guidelines of work (good). Thus the hypothesis in this study which states that job stress has a significant positive effect on employee service satisfaction of Financial Services Cooperative in Denpasar proven.

The result of this analysis is in accordance with the statement made by Karambut (2012) which states that the work stress experienced by employees and not immediately addressed will have an impact on behaviour that is not expected by the organization, such as low employment and decreased organizational commitment of employees. The results of this study in accordance with research Suhanto (2009), Damar, et al. (2017), Annisa, Setyawan, \& Susila (2017), Ameer, Bhatti, \& Baig (2014), and (Bemana, Moradi, Ghasemi, Taghavi, \& Ghayoor, 2013) stating that job stress greatly affect job satisfaction.

\section{The Influence of Employee Empowerment Against Organizational Commitment at Denpasar Financial Services Cooperative}

Based on the results of testing on the effect of employee empowerment to organizational commitment, showed that employee empowerment has a positive but not significant effect on organizational commitment at Denpasar Financial Services Cooperative. Thus the hypothesis in this study which states that employee empowerment has a significant positive effect on organizational commitment at the Financial Services Cooperative Denpasar. In terms of employee empowerment indicators, 2 indicators score above average is involved in determining the goals of the organization (good) and input that I give received in the planner of organization activities (very good). Thus the hypothesis in this study which states that employee empowerment has a significant positive effect on organizational commitment to the Financial Services Cooperative in Denpasar is not proven.

The results of this analysis are in accordance with the statement made by (Abdullah, Almadhoun, \& Ling, 2015) which states that empowerment will make employees do a good job and encourage employees to make better efforts on behalf of the organization, the impact resulting from high employee empowerment is the increase of satisfaction work, organizational commitment, employee fairness level, performance, motivation and productivity. The results of this study are in accordance with the research of Widyaningrum (2015), Praptadi (2009), Hanaysha \& Tahir (2016), Maina (2016), and (Insan, 2013) stating that there is a significant influence of empowering organizational commitment.

\section{The Influence of Job Stress on Organizational Commitment at Denpasar Financial Services Cooperative}

Based on the results of testing on the effect of work stress on organizational commitment, showed that job stress has a positive but significant impact on organizational commitment at the Financial Services Cooperative Denpasar. Thus the hypothesis in this study which states that job stress has a significant positive effect on organizational commitment at the Financial Services Cooperative Denpasar. In terms of job stress indicator, 3 indicators score above the average that works faster than the ability (good), carrying 
out the work exceeds the efforts of employees in general (good) and do new things without the guidelines of work (good). Thus the hypothesis in this study which states that job stress has a significant positive effect on organizational commitment at the Financial Services Cooperative in Denpasar proven. The results of this analysis in accordance with the statement put forward by Wibowo, Riana, \& Putra (2015) stating that job stress is important to manage because of the impact of low occupational stress can make employees do their best to maintain organizational commitment. The results of this study in accordance with research Mamahit (2016), Wibowo et al. (2015), and Pitri (2017) stating that there is work stress positively and insignificant to organizational commitment.

The Influence of Job Satisfaction Against Organizational Commitment at Denpasar Financial Services Cooperative.

Based on the results of testing on the effect of job satisfaction on organizational commitment, shows that job satisfaction has a positive but not significant effect on organizational commitment at Denpasar Financial Services Cooperative. Thus the hypothesis in this study which states that job satisfaction has a significant positive effect on organizational commitment at the Financial Services Cooperative Denpasar. In terms of job satisfaction indicators, 2 indicators score above average is satisfied with my colleagues (very good) and the leadership always gives support in every job (very good). Thus the hypothesis in this study which states that job satisfaction has a significant positive effect on organizational commitment at the Financial Services Cooperative in Denpasar is not proven. Job satisfaction has a positive but insignificant effect since many similar businesses are also marketing similar products.

The results of this analysis in accordance with the statement presented by (Parwita, 2013) stating that an employee will be satisfied while working, then he will do his best to get the job done. Job satisfaction is basically how big the positive or negative role that employees show to their work. Individuals who are satisfied will have a high commitment to the company. The results of this study in accordance with research Febriwanti et al (2017), Siallangan (2014),
Maulana \& Syah (2016), (Elnaga \& Imran, 2013), Muhadi, (2007) and Taurisa \& Ratnawati (2012).

\section{The Role of Job Satisfaction in the Mediating Effects of Employee Empowerment Against Organizational Commitment in Financial Services Cooperative Denpasar}

Based on Hair et. al. (2010), satisfaction is a perfect mediation between empowerment of commitment, because the direct relationship of empowerment to commitment is insignificant, while indirect relationships indicate that both empowerments of satisfaction and satisfaction with commitment are significant. The results of this analysis are not in accordance with the statement put forward by (Febriwanti et al., 2017) which states that the direct impact of employee empowerment on job satisfaction is greater than the indirect influence between empowerment of organizational commitment, so as to increase organizational commitment is chosen direct path. According to previous research, this means that the effect of empowerment of organizational commitment with the mediation of job satisfaction contributes less when compared to the effect of employee empowerment on organizational commitment, so it can be said that job satisfaction is not a perfect mediation of organizational commitment.

\section{The Role of Job Satisfaction in Mediating the Effects of Working Stress on Organizational Commitment at Financial Services Cooperative Denpasar}

Based on Hair \& et al. (2010), satisfaction is not a mediation between stress and commitment, because the indirect relationship of stress to satisfaction is significant whereas satisfaction with commitment is not significant. The results of this analysis are not in accordance with the statement put forward by Wibowo et al. (2015) which states that the direct effect of job stress on job satisfaction is less than the indirect effect of job stress on organizational commitment so that to increase the commitment of organizational chosen direct path. According to previous research, this means that the effect of job stress on organizational commitment with the mediation of job satisfaction contributes more when compared with the effect of job stress on organizational commitment, so it can be said that 
job satisfaction is not a perfect mediation of organizational commitment.

\section{CONCLUSIONS}

Based on the results discussed above, therefore it can be presented several conclusions: 1) Employee empowerment has a positive and insignificant effect on job satisfaction at Financial Services Cooperative in Denpasar. This result means that although employee empowerment increases, but the increase in job satisfaction of employees of Financial Services Cooperative in Denpasar is not significant. 2) Working stress has a positive and significant effect on job satisfaction in Finance services Cooperative in Denpasar. These results give meaning that the more controlled job stress of employee hence job satisfaction of employees of Financial Services Cooperative in Denpasar increased significantly. 3) Employee empowerment has a positive but insignificant effect on organizational commitment in Finance Services Cooperative in Denpasar. This result gives meaning even though employee empowerment is increasingly concerned, but the increase of organizational commitment in Financial Services Cooperative in Denpasar is not significant. 4) Working stress has a positive and significant impact on organizational commitment in Finance Services Cooperative in Denpasar. This gives the meaning that the more controlled employment stress employees then the organizational commitment of employees of the Financial Services Cooperative in Denpasar increased significantly. 5) Job satisfaction has a positive but insignificant effect on organizational commitment in Finance Services Cooperative in Denpasar. This means that although job satisfaction is increasing, the increase in organizational commitment to the Financial Services Cooperative in Denpasar is not significant. 6) Satisfaction is a perfect mediation between empowerment of commitment, because the direct relationship of empowerment to commitment is insignificant, while indirect relationships indicate that both empowerments of satisfaction and satisfaction with commitment is significant. 7) Satisfaction is not mediation between stress to commitment, because the indirect relationship stress to satisfaction is significant while satisfaction with commitment is not significant.

\section{REFERENCES}

Abdullah, A. G. K. B., Almadhoun, T. Z., \& Ling, Y. L. (2015). Psychological empowerment, job satisfaction and commitment among Malaysian secondary school teachers. Asian Journal of Educational Research, 3(3), 34-42.

Ameer, M. H., Bhatti, S., \& Baig, S. (2014). Impact of Employee Empowerment on Job Satisfaction. Developing Country Studies, 4(9).

Annisa, N. N., Setyawan, A. A., \& Susila, I. (2017). Pengaruh Stres Kerja Terhadap Kinerja Karyawan Dengan Kepuasan Kerja Sebagai Variabel Intervening. Universitas Muhammadiyah Surakarta.

Bemana, S., Moradi, A., Ghasemi, M., Taghavi, S. M., \& Ghayoor, A. H. (2013). The Relationship among Job Stress and Job Satisfaction in Municipality Personnel in Iran. World Applied Sciences Journal, 22(2).

Cotton, J. L., \& Tuttle, J. M. (1986). Employee Turnover: A Meta-Analysis and Review with Implications for Research. Academy of Management Review, 11(1), 55-70.

Elnaga, A., \& Imran, A. (2013). The Effect of Training on Employee Performance. European Journal of Business and Management, 5(4).

Febriwanti, F., Zulfadil, \& Samsir. (2017). Pengaruh Kepemimpinan, Fokus pada Konsumen, Pemberdayaan Karyawan, dan Manajemen Proses terhadap Kepuasan Kerja Karyawan PT Telkomsel Area Pekanbaru. Jurnal SOROT, 12(1), 55-70.

Ghozali, I., \& Latan, H. (2012). Partial Least Square: Konsep, Teknik dan Aplikasi SmartPLS 2.0 M3. Semarang: Badan Penerbit Universitas Diponegoro.

Hair, J., \& et al. (2010). Multivariate Data Analysis (7th edition). Harlow: Pearson Education Limited.

Hanaysha, J., \& Tahir, P. R. (2016). Examining the Effects of Employee Empowerment, Teamwork, and Employee Training on Job Satisfaction. Procedia - Social and Behavioral Sciences, 219, 272-282. doi:10.1016/j.sbspro.2016.05.016

Huselid, M. A. (1995). The Impact of Human Resource Management Practices on Turnover, Productivity, and Corporate Financial Performance. Academy of Management Journal, 38(3), 635-672. doi:10.5465/256741

Insan, A. N. (2013). The Effect of Empowerment of the Organizational Commitment and the Job Satisfaction of the Employees of the National Electricity Company (Ltd.) in South Sulawesi 
Province Indonesia. Asian Transactions on Basic \& Applied Sciences (ATBAS), 3(4).

Karambut, C. A. (2012). Analisis Pengaruh Kecerdasan Emosional, Stres Kerja dan Kepuasan Kerja terhadap Komitmen Organisasional (Studi pada Perawat Unit Rawat Inap RS Panti Waluya Malang). Jurnal Aplikasi Manajemen, 10(3).

Maina, M. W. (2016). Influence of Employee Structural Empowerment on Organizational Commitment in Kenya Civil Service. Strategic Journal of Business \& Change Management, 31(1).

Mamahit, N. A. (2016). Pengaruh Gaya Kepemimpinan, Konflik Kerja Dan Stres Kerja Terhadap Kinerja Pegawai Dengan Komitmen Organisasi Sebagai Variabel Intervening. Jurnal Riset Bisnis Dan Manajemen, 4(3).

Maulana, T. (2015). Pengaruh Pemberdayaan Karyawan, Lingkungan Kerja, dan Kompensasi Terhadap Kepuasan Kerja dan Turnover Intention. Universitas Esa Unggul.

Maulana, T., \& Syah, T. Y. R. (2016). Faktor - Faktor yang Mempengaruhi Kepuasan Kerja dan Turnover Intention. Media Manajemen Jasa, 2(2).

Muhadi. (2007). Analisis Pengaruh Kepuasan Kerja Terhadap Komitmen Organisasional Dalam Mempengaruhi Kinerja Karyawan (Studi pada Karyawan Administrasi Univeristas Diponegoro). Universitas Diponegoro.

Muhammad, I. G., \& Abdullah, H. H. (2016). Assessment of Organizational Performance: Linking The Motivational Antecedents of Empowerment, Compensation and Organizational Commitment. International Review of Management and Marketing, 6(4).

Parwita, G. B. S. (2013). Pengaruh Kepuasan Kerja terhadap Komitmen Organisasi dan Disiplin Kerja (Studi pada Dosen Yayasan Universitas Mahasaraswati Denpasar). Universitas Mahasaraswati.

Pitri, N. (2017). Pengaruh Stres Kerja, Kompensasi dan Pengembangan Karir Terhadap Komitmen Organisasional Perawat di Rumah Sakit Jiwa Mutiara Sukma Mataram Provinsi NTB. JMM: Jurnal Magister Manajemen Universitas Mataram, 6(4). doi:http://dx.doi.org/10.29303/jmm.v6i4.198

Praptadi, T. (2009). Analisis Pengaruh Budaya Organisasi dan Pemberdayaan Terhadap Komitmen Organisasional Dalam Meningkatkan Kinerja Pegawai (Studi pada Pegawai Account Representative di Kantor Pelayanan Pajak (KPP) Pratama Kota Semarang). Universitas Diponegoro.
Schuler, R. S., \& MacMillan, I. C. (1984). Gaining competitive advantage through human resource management practices. Human Resource Management, 23(3), 241-255. doi:10.1002/hrm.3930230304

Siagan, S. P. (2004). Teori Pengembangan Organisasi (Edisi ke 1). Bandung: Bumi Aksara.

Siallangan, H. (2014). Pengaruh Sistem Penggajian, Pemberdayaan dan Motivasi Terhadap Kinerja Pegawai Kecamatan Sitolu Ori Kabupaten Nias Utara. JMBS: Jurnal Manajemen \& Bisnis Sriwijaya, 12(4). doi:https://doi.org/10.29259/jmbs.v12i4.3180

Solimun. (2011). Analisis Variabel Moderasi Dan Mediasi. Program Studi Statistika FMIPA UB $31 \mathrm{~V}$.

Suhanto, E. (2009). Pengaruh Stres Kerja dan Iklim Organisasi Terhadap Turnover Intention Dengan Kepuasan Kerja Sebagai Variabel Intervening (Studi di Bank Internasional Indonesia). Universitas Diponegoro.

Taurisa, C. M., \& Ratnawati, I. (2012). Analysis of Effect of Organizational Culture and Organizational Commitment on Job Satisfaction in Improving The Performance of Employees (Study on PT. Sido Muncul Kaligawe Semarang). Jurnal Bisnis Dan Ekonomi (JBE), 19(2), 170 - 187.

Wibowo, I. G. P., Riana, I. G., \& Putra, M. S. (2015). Pengaruh Stres Kerja Terhadap Kepuasan Kerja Dan Komitmen Organisasional Karyawan. E-Jurnal Ekonomi Dan Bisnis Universitas Udayana, 4(2), 125-145.

Widyaningrum, P. (2015). Pengaruh Kepuasan Kerja, Keadilan Organisasi, dan Pemberdayaan Karyawan terhadap Komitmen Organisasi pada PT. Asuransi Sinarmas. Universitas Atma Jaya Yogyakarta

Yulianti, A. (2011). Faktor- Faktor yang Berpengaruh Terhadap Audit Delay (Studi Empiris Pada Perusahaan Manufaktur yang Terdaftar di Bursa Efek Indonesia pada tahun 2007-2008. Universitas Negeri Yogyakarta. 